\title{
Solace for a difficult journey
}

Excerpts from a Family Medical Dictionary

Rebecca Brown

Madison, Wisconsin: University of

Wisconsin Press; 2001

113 pp \$19.95 (cloth) ISBN 0-299-18970

\section{A}

mid the increasing number of best-selling memoirs many

come with gratuitous and shocking revelations of physical and mental illness, death, addiction, poverty, abuse, criminality and intimate sexual exploits. In these instances, the discerning physician may wonder whether exposing emotionally vulnerable individuals to such harrowing narratives might actually yield negative consequences.

As physicians, do we prescribe books as medicine? Should we suggest grieving patients read for example, Joan Didion's The Year of Magical Thinking, Simone de Beauvoir's A Very Easy Death, or Phillip Roth's Patrimony, which deal respectively with the death of a husband, mother, and father? Can narratives offer solace and wisdom to distressed patients, a guide to the perplexed, or a way of being less alone on a painful journey? Or do such narratives, like certain pharmaceutical remedies, lead to adverse reactions?

It depends on the narrative.

A sensitive clinician knows that empathy for the patient's experience is essential, and that our facility to prescribe narratives (both spoken and written) of authentic support and understanding may be an inestimable therapeutic resource.

Rebecca Brown, a former home care worker and an award-winning US

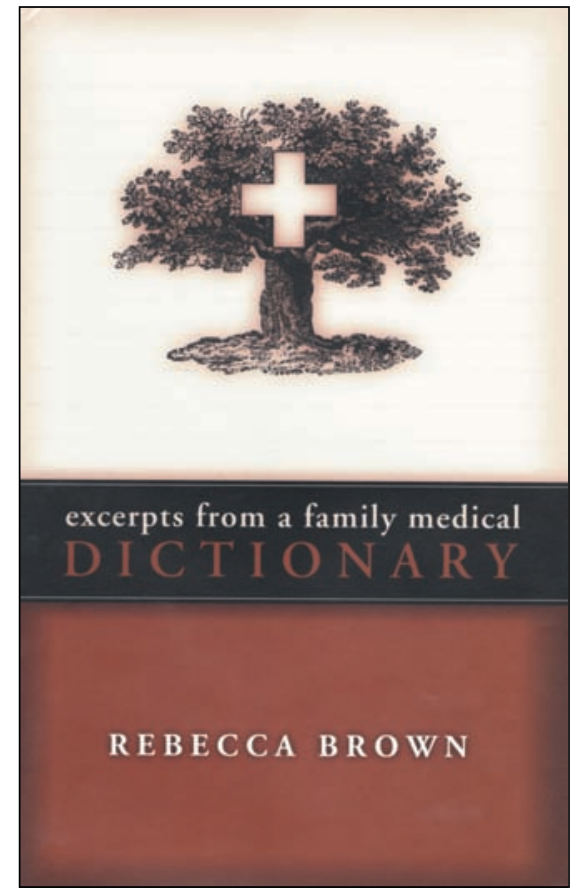

author of 7 novels and professor of literature, has provided just such a resource. In this slender volume (II3 pages) Brown conveys an intimate account of her mother's illness during her last months of life, detailing the raw experience of suffering with an unadorned simplicity of tone and voice. Such a chronicle pays homage to the deceased and provides a model for the living as they struggle with a loved one's illness and their grief. This book, which can be read in 3 hours, would inform health-care students and professionals, as well as a general readership.

The elegiac narrative begins as the author learns her mother has abdominal cancer. The writing style is laconic, closely observed and unsenti- mental, yet profoundly personal. Brief chapter-headings - anemia, metastasis, chemotherapy, and so on - reflect the steps in her mother's passage towards death and Brown's support for her during her last months. The book title, Excerpts from a family medical dictionary, repeats this leitmotiv by providing an objective clinical heading, instead of a subjective expression of loss and suffering. This contextual structure affords the reader an opportunity to inject his or her own story under the subheadings; to use them, in essence, as a template for their own narrative.

But this clinical context does not undermine the book's emotional impact. To the extent that death is our own last chapter, we struggle when reading about its finality - the loss of others and ourselves.

It is a lovingly written book with many outstanding passages. Of note to the clinician is Brown's illustration of the delicacy with which her mother's doctor narrates the impending loss.

He sat down next to me and said something I forgot when he said the next thing which was that they had found a tumor. He didn't say anything for a few seconds. He was just looking at me to make sure I got it. When I thought about this later, I could tell that he had done this before. He did it kindly, carefully. [p. I6]

He took a pencil and drew a circle where the tumor had been and a line where he'd cut to remove it. He told me it had gone well. There had been no excessive bleeding and he didn't expect her to have complications in her recovery from her surgery...He made some X-marks with his pencil. "We found some abnormal cells here...and here..." He 
kept making X marks... I started to count them then I stopped...it looked like it had spread to all of these places. [p. 22]

In the following chapter Brown describes the progression of the cancer and her mother's deliberate and methodical preparations for death: a lawyer's appointment, signing a will, considering a hospice, discussing cremation, and then waiting for death.

It felt terrible to wait for that, as if we wanted it to happen. I don't remember when I stopped hoping my mother would remain alive. [p. 28]

The impact of numerous passages make them worth a second read. Here, Brown achingly portrays chemotherapy's impact on her mother as well as herself.

The vomiting exhausted her. There was no food in her stomach because she hadn't eaten. What was in her stomach was blood, clots, and bubbles and strings of it. The black was partially digested. There was phlegm around it sometimes, thick and viscous, white or green...I knew each time it happened it was hurting her. It was not only that she was in the process of dying, it was that she was immediately, right then, particularly, acutely in pain...I wanted to take it from her but all I could do was hold the bucket under her chin... [p. 56]

Brown, her sister, and her brother care for their mother; Brown washes her wasted body, watches her fitful sleep, fearing breath will cease. When, at last, her mother dies, her body is cremated and the children take their mother's ashes to a canyon where they all used to go to collect wild flowers.

The ashes were mostly gray and black and white but not all of them. Among them there were flecks of blue, like the egg of a bird, or green like an after-dinner mint, and brownish gold like sand. Some of the ashes were pretty and I wondered what they were. [p. II2] "[My brother]...picked up the pot...threw it across to the other side of the canyon... we looked down below ...to where the earth had cracked, a place we could not see. Then the water carried her away." [p. II3]

The writer's reliability, truthfulness and authentic voice allow readers to establish faith in her as a guide through one of life's most difficult experiences.
Brown's book proves that illness narratives have the potential to accurately inform readers about the course of illness and the manifold roles and tasks of the patient, family members and health care providers as they navigate their way from life to death.

With the proliferation of muchhyped tabloidesque narrative, we must never forget the power of some stories

\section{Room for a view}

\section{Discharge day}

$\mathrm{E}$ lla was going home. She had been admitted to hospital a few days before I started my month as attending physician on the medical ward. The history in her chart was all too familiar: 89-year-old woman from nursing home; Alzheimer's disease; inadequate oral intake; admitted with dehydration, hypernatremia and acute renal failure. She had a shock of frizzly white hair and a face crisscrossed with myriad fine wrinkles. Her eyes betrayed her confusion. I quickly curtailed my efforts at conversation after receiving a few mumbled, barely comprehensible words in reply.

Abnormalities found in her laboratory test results had responded rapidly to treatment, but each time we stopped giving her intravenous fluids, her serum creatinine level climbed slowly but inexorably above the normal range. Her dementia had progressed to the point that while eating she would often forget that there was food in her mouth. As a result, the staff were feeding her with erratic success. Ella was clearly incapable of making decisions about her care. When I suggested that we arrange a family conference, I was told that her common-law husband, Zoltan, was already a patient at our hospital.

Zoltan and Ella had been together for 743 years, and they always said that it had 空 been "love at first sight." Ella was a supervisor at a hospital in Montreal, and Zoltan, who was 15 years younger than Ê Ella, worked as a technician in the blood bank. After their retirements, they lived on a small apartment in Toronto until to inform, reassure and humanize the experience of illness and suffering for each of us.

\section{Ronald Ruskin}

Department of Psychiatry

University of Toronto

Director, Day Hospital

Mount Sinai Hospital

Toronto, Ont. their numerous health problems and increasing disability forced them 3 years ago to move into a nursing home where they shared a room.

Zoltan had sleep apnea and COPD. Half a year ago, he was sent to our hospital because of episodes of decreased level of consciousness, and shortly therafter he developed acute respiratory failure. He had been in the ICU ever since, ventilated through a tracheostomy. Every effort to wean him had failed. Alert, intellectually intact, and fully aware of his situation, he continued to affirm his desire for aggressive medical care.

Meanwhile, Ella's level of functioning had deteriorated. The nurse practitioner caring for Zoltan in the ICU told me sadly, "She came to visit him once about 5 months ago. She didn't even recognize him."

A small group of staff from the medical ward trooped down to the ICU to meet with Zoltan. He was a large man with keen eyes and a broad face that was strikingly smooth and unlined. When we gathered around his bed and told him why we were there, his startled look made us realize, with sudden embarrassment, that no one had informed him that his wife had been in the hospital for the past week. After explaining Ella's situation to him, we raised the questions of whether Ella should have a feeding gastrostomy tube, and whether the nursing home should send her back to hospital if she became ill in the future. Zoltan listened attentively. Unable to speak because of his tracheostomy, he communicated by writing on a clipboard. $\mathrm{He}$ 